\title{
Purification and Properties of Amycolatopsis Mediterranei DSM 43304 Lipase and Its Potential in Flavour Ester Synthesis
}

\author{
Dharmendra Dheeman \\ Technological University Dublin, dharmendra.dheeman@student.dit.ie \\ Gary Henehan \\ Technological University Dublin, gary.henehan@tudublin.ie \\ Jesus Maria Frias \\ Technological University Dublin, Jesus.Frias@tudublin.ie
}

Follow this and additional works at: https://arrow.tudublin.ie/schfsehart

Part of the Biochemistry Commons

\section{Recommended Citation}

Dheeman, D. S., Henehan, G.T.M. and Frias, J.M. (2011) Purification and properties of Amycolatopsis mediterranei DSM 43304 lipase and its potential in flavour ester synthesis. Bioresource Technologies 102(3) 3373-3379. doiL10.1016/j.biortech.2010.11.074

This Article is brought to you for free and open access by the School of Food Science and Environmental Health at ARROW@TU Dublin. It has been accepted for inclusion in Articles by an authorized administrator of ARROW@TU Dublin. For more information, please contact arrow.admin@tudublin.ie, aisling.coyne@tudublin.ie, gerard.connolly@tudublin.ie.

Funder: DIT ABBEST Research Scholarship (PB 03557/ 2007)

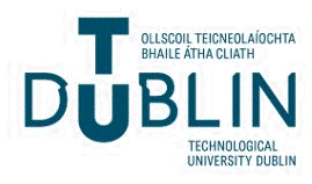


1 Purification and properties of Amycolatopsis mediterranei DSM 43304 lipase

2 and its potential in flavour ester synthesis

3

4

5 Dharmendra S. Dheeman, Gary T. M. Henehan*, Jesus M. Frías

6

7

8 School of Food Science and Environmental Health, Dublin Institute of Technology,

9 Cathal Brugha Street, Dublin 1, Ireland

10

11

12

13

14 *Corresponding author: Phone: +353 14024408; Fax: +353 14024459;

15 E-mail addresses: dheeman@gmail.com (D. S. Dheeman); gary.henehan @ dit.ie (Gary

16 Henehan); jesus.frias@ dit.ie (Jesus Frías)

17

18

19

20

21

22
AML: A. mediterranei DSM 43304 lipase

p-NPP: $p$-Nitrophenyl Palmitate 


\section{Abstract}

An extracellular thermostable lipase from Amycolatopsis mediterranei DSM 43304

25 has been purified to homogeneity using ammonium sulphate precipitation followed by

26 anion exchange chromatography and hydrophobic interaction chromatography. This

27 protocol resulted in 398 fold purification with $36 \%$ final recovery. The purified $A$.

28 mediterranei DSM 43304 lipase (AML) has an apparent molecular mass of $33 \mathrm{kDa}$. The N-

29 terminal sequence, AANPYERGPDPTTASIEATR, showed highest similarity to a lipase

30 from Streptomyces exfoliatus. The values of $K_{m}^{a p p}$ and $V_{\max }^{a p p}$ for $p$-nitrophenyl palmitate $(p$ -

$31 \mathrm{NPP})$ under optimal temperature $\left(60^{\circ} \mathrm{C}\right)$ and $\mathrm{pH}(8.0)$ conditions were $0.10 \pm 0.01 \mathrm{mM}$ and

$32 \quad 2.53 \pm 0.06 \mathrm{mmol} / \mathrm{min} \mathrm{mg}$, respectively. The purified AML displayed significant activity

33 towards a range of short and long chain triglycerides. It was most active on triolein and a

34 wide range of $p$-nitrophenyl esters, with a preference for an acyl chain length of C8:0.

35 Hydrolysis of glycerol ester bonds occurred non-specifically. The purified AML displayed

36 significant stability in the presence of organic solvents (40\% v/v) and catalyzed the

37 synthesis of flavour ester isoamyl acetate in free and immobilized states.

38

39 Keywords: Actinomycete lipase; Amycolatopsis mediterranei; Purification;

40 Characterization; Ester synthesis 


\section{Introduction}

Lipases are among the most versatile of the enzyme classes and are used in a

43 number of applications in various industries, including the pharmaceutical, food, detergent,

44 cosmetic, oleochemical, fat-processing, leather, textile and paper industries (Gupta et al.

45 2004; Pandey et al. 1999). Current research on lipases, mainly of microbial origin, has

46 increased in volume because of their great commercial potential (Dandavate et al., 2009;

47 Silva et al., 2009). As the applications increase, the availability of lipases possessing

48 satisfactory operating characteristics for specific purposes is a limiting factor. Since many

49 industrial processes operate at temperatures exceeding $45^{\circ} \mathrm{C}$, lipases should ideally have

50 catalytic activity and stability around $50^{\circ} \mathrm{C}$ (Sharma et al., 2002). Thermophilic

51 microorganisms have been the focus of a number of investigations of novel sources of

52 lipases that are stable and optimally functional at high temperatures (Berekaa et al., 2009;

53 Nawani and Kaur, 2007), although in recent years a few mesophilic actinomycetes have

54 also been reported to produce thermoactive lipases (Abramić et al., 1999; Côté and

55 Shareck, 2008; Zhang et al., 2008).

56 Lipases from actinomycetes have not been studied as intensively as those from other

57 bacteria. In a previous paper from this laboratory we reported the presence of a novel lipase

58 in crude extracts of a mesophilic actinomycete Amycolatopsis mediterranei DSM 43304

59 (Dheeman et al., 2010). Characterization of this A. mediterranei DSM 43304 lipase (AML)

60 activity indicated it had high thermostability and organic solvent stability indicating its

61 potential in organic synthesis. This has led to further interest in purification of AML and

62 investigating its potential in organic synthesis. In the present work we report the

63 purification and characterization of AML and evaluate its potential in the synthesis of an 
64 industrially important flavour ester, isoamyl acetate. The main highlight of our study is the

65 potential of purified AML in the synthesis of flavour ester through direct esterification of

66 isoamyl alcohol using acetic acid as an acyl donor.

\section{2. Materials and methods}

$68 \quad 2.1$ Chemicals

69 Analytical reagent grade chemicals were obtained from commercial sources at the 70 purest grade available. Unless otherwise mentioned, all chemicals were purchased from 71 Sigma-Aldrich Ireland Ltd.

$72 \quad 2.2$ Microorganism and lipase production

74 School of Biology, Newcastle University, UK. The strain was identified as a lipase

75 producer on olive oil-rhodamine B agar. The lipase was produced in optimized production 76 medium as previously reported (Dheeman et al., 2010).

\section{$77 \quad 2.3$ Lipase activity assays}

\subsubsection{Spectrophotometric assay}

79 Lipase activity was routinely assayed using $p$-nitrophenyl palmitate ( $p$-NPP) as

80 substrate according to Winkler and Stuckmann (1979) with some modifications as

81 described previously (Dheeman et al., 2010). The assay was typically run for $10 \mathrm{~min}$ at

$8260^{\circ} \mathrm{C}$ before termination by addition of $2.0 \mathrm{ml}$ of $0.2 \mathrm{M} \mathrm{Na}_{2} \mathrm{CO}_{3}$. Liberated $p$-nitrophenol

83 ( $p$-NP) was determined at $410 \mathrm{~nm}\left(\varepsilon_{410 \mathrm{~nm}}: 0.0169 / \mu \mathrm{mol} \mathrm{cm}\right)$ using a UNICAM UV2 2000E

84 UV-VIS Spectrophotometer (Cambridge, UK). Appropriate blanks were used to subtract 85 the absorbance corresponding to the reaction mixture other than that produced by the 
86 specific hydrolysis of $p$-NPP. One international unit (IU) of lipase activity was defined as

87 the amount of enzyme needed to liberate $1 \mu$ mol of $p$-NP per minute under the assay

88 conditions.

\section{$89 \quad$ 2.3.2 Titrimetric assay}

91 Burkert et al. (2004). Incubations were carried out at $60^{\circ} \mathrm{C}$ and $\mathrm{pH} 8.0$ for $10 \mathrm{~min}$. The

92 enzymatic reaction was initiated by addition of $1 \mathrm{ml}$ of appropriately diluted enzyme

93 solution to the reaction mixture $(5 \mathrm{ml})$ and stopped by the addition of $15 \mathrm{ml}$ of ethanol.

94 Control was carried out similarly, except that the enzyme solution was added after the

95 addition of ethanol. One IU of lipase activity was defined as the amount of enzyme that

96 caused the release of one $\mu \mathrm{mol}$ of free fatty acid per minute under test conditions. For

97 substrate specificity studies similar method was used but using various substrates.

\section{$98 \quad 2.4$ Purification of AML}

After $96 \mathrm{~h}$, the cells were separated by centrifugation at $10,000 \times \mathrm{g}$, at $4^{\circ} \mathrm{C}$, for 10

$100 \mathrm{~min}$, and the supernatant was recovered and filtered ( $0.2 \mu \mathrm{m}$ filter, Millipore). Unless

101 otherwise mentioned, all purification steps were performed at $4^{\circ} \mathrm{C}$. The extracellular lipase

102 was concentrated from the filtrate by stepwise saturation to $40 \%$ ammonium sulphate. The

103 precipitate was collected by centrifugation $\left(14,000 \times \mathrm{g}\right.$ for $10 \mathrm{~min}$ at $\left.4^{\circ} \mathrm{C}\right)$, dissolved in 10

$104 \mathrm{mM}$ Tris- $\mathrm{HCl}$ buffer, $\mathrm{pH} 8.0$ and dialyzed against the same buffer for $12 \mathrm{~h}$. The dialyzed

105 material was centrifuged $\left(12,000 \times \mathrm{g}\right.$ for $10 \mathrm{~min}$ at $\left.4^{\circ} \mathrm{C}\right)$ and the supernatant was applied to

106 a Q Sepharose HP column $(2.5 \times 10 \mathrm{~cm}, 30 \mathrm{ml}$ gel $)$. The column was preequilibrated with

$10710 \mathrm{mM}$ Tris-HCl buffer, $\mathrm{pH} 8.0$ (buffer A). Bound protein was eluted with a step gradient

108 of increasing $\mathrm{NaCl}$ concentration from $0.2 \mathrm{M}$ to $1.0 \mathrm{M}$ using 3.0 column volumes of buffer 
109 A at a flow rate of $108 \mathrm{ml} / \mathrm{h}$. Fractions were collected and analyzed for lipase activity and

110 protein content. Active fractions containing high lipase activity were pooled and

111 concentrated by ultrafiltration using a $10 \mathrm{kDa}$ centricon (Amicon, USA), and applied to a

112 Toyopearl Phenyl-650M column $(2.5 \times 10 \mathrm{~cm}, 40 \mathrm{ml}$ gel $)$. The column was preequilibrated

113 with $10 \mathrm{mM}$ Tris buffer, $\mathrm{pH} 8.0$, containing $20 \%$ ammonium sulphate (buffer B) at room

114 temperature. Equilibration of Toyopearl Phenyl-650M gel with sample at room temperature

115 allowed $100 \%$ of the lipase to be bound. After a three column volume wash with buffer B,

116 the bound protein was eluted with three column volumes of decreasing step gradient of

117 ammonium sulphate from $20-0 \%$ and three column volumes of increasing step gradient of

118 isopropanol from $0-30 \%$ in buffer $\mathrm{A}$ at a flow rate of $125 \mathrm{ml} / \mathrm{h}$. Fractions containing high

119 lipase activity were pooled and tested for purity on SDS-PAGE gels. The gels were stained

120 with silver nitrate and the molecular mass of the purified enzyme was estimated using

121 standard protein markers (BioRad Laboratories, CA, USA).

$122 \quad 2.5$ Gel electrophoresis and zymography

123 SDS-polyacrylamide gel electrophoresis (SDS-PAGE) was carried out in $12.5 \%$

$124(\mathrm{w} / \mathrm{v})$ gels at room temperature (ATTO AE-6450, Tokyo, Japan) as previously reported

125 (Dheeman et al., 2010). For activity staining, zymographic analysis was performed,

126 essentially as described by Prim et al. (2003).

$127 \quad 2.6$ N-terminal sequence analysis

128 The purified protein band on SDS gel was transferred to a polyvinylidene difluoride 129 membrane (Immobilon ${ }^{\circledR}$-P PVDF, Millipore) by semidry electroblotting (ATTO Horizblot 130 AE-6677, Tokyo, Japan), and stained with Coomassie Brilliant Blue R 250. Automated 
131 Edman protein degradation was performed using a protein sequencer (ABI Procise 491

132 Edman micro sequencer connected to a 140C PTH amino acid analyzer).

\section{$133 \quad 2.7$ The effect of $\mathrm{pH}$ and temperature on activity and stability}

134 The effect of $\mathrm{pH}$ and temperature on purified AML was investigated by using $p$ -

$135 \mathrm{NPP}$ as the substrate. The optimal $\mathrm{pH}$ of the purified enzyme was determined at $60^{\circ} \mathrm{C}$ over 136 a pH $\mathrm{H}^{60^{\circ} \mathrm{C}}$ range of 2-10 at constant molarity $(50 \mathrm{mM})$ in different buffers (glycine- $\mathrm{HCl}(\mathrm{pH}$ 137 2.0-3.0), citrate-phosphate ( $\mathrm{pH} 3.0-6.0)$, sodium phosphate ( $\mathrm{pH}$ 6.0-8.0), Tris- $\mathrm{HCl}(\mathrm{pH} 8.0$ 138 and 9.0) and 2-amino-2-methyl-1,3-propanediol (ammediol) buffer ( $\mathrm{pH} 9.0-10.0)$ ) . The $\mathrm{pH}$ 139 stability was studied by incubating the purified AML in selected buffers of $\mathrm{pH}$ range 2-12

140 for $24 \mathrm{~h}$ at $20^{\circ} \mathrm{C}$. The residual enzyme activity was measured by spectrophotometric assay 141 at $60^{\circ} \mathrm{C}, \mathrm{pH} 8.0$. The optimum temperature of the purified enzyme was determined by 142 measuring the enzyme activity at various temperatures $\left(20-80^{\circ} \mathrm{C}\right)$ in $50 \mathrm{mM}$ Tris- $\mathrm{HCl}$ 143 buffer, $\mathrm{pH}$ 8.0. Thermostability was determined by incubating purified lipase in $20 \mathrm{mM}$ 144 Tris-HCl buffer, $(\mathrm{pH} 8.0)$ at various temperatures $\left(60-90^{\circ} \mathrm{C}\right)$ for $3 \mathrm{~h}$ and residual activity 145 was analyzed by spectrophotometric assay at $60^{\circ} \mathrm{C}, \mathrm{pH}$ 8.0.

\section{$146 \quad 2.8$ Determination of kinetic constants}

147 Initial rates measurements with $0.59 \mu \mathrm{g}$ of purified AML were performed in $50 \mathrm{mM}$

148 Tris- $\mathrm{HCl}$ buffer, $\mathrm{pH} 8.0$ at $60^{\circ} \mathrm{C}$ with increasing concentration of $p$-NPP $(0.02-0.93 \mathrm{mM})$.

149 Kinetic constants were obtained by fitting experimental data to the Michaelis-Menten 150 equation using EnzFitter (Biosoft, Cambridge, UK) to obtain estimates of Michaelis 151 constant $\left(K_{m}^{a p p}\right)$ and maximal velocity $\left(V_{\max }^{a p p}\right)$. Turnover number $k_{c a t}^{a p p}$ was calculated using 152 the equation $k_{c a t}^{a p p}=V_{\max }^{a p p} /[\mathrm{E}]_{\mathrm{T}}$, where $[\mathrm{E}]_{\mathrm{T}}$ is the molar amount of enzyme in the reaction. 


\subsection{Determination of substrate range}

To determine the substrate range of the purified AML, the relative activities were

155 investigated against a series of $p$-nitrophenyl esters ( $p$-nitrophenyl acetate $(\mathrm{C} 2: 0), p$ -

156 nitrophenyl butyrate (C4:0), p-nitrophenyl caproate (C6:0), p-nitrophenyl caprylate (C8:0),

$157 \quad p$-nitrophenyl laurate $(\mathrm{C} 12: 0), p$-nitrophenyl myristate $(\mathrm{C} 14: 0)$ and $p$-nitrophenyl palmitate

158 (C16:0)) differing in fatty acyl chain length. AML substrate specificity for triacylglycerides

159 was analyzed using a variety of triacylglyceride substrates including olive oil, corn oil,

160 castor oil, sunflower oil, rape seed oil, linseed oil, cotton seed oil and jojoba oil. Also

161 relative activities of purified AML against a series of triacylglycerol substrates (trioctanoin

162 (C8:0), tripalmitin (C16:0), tristearin $(\mathrm{C} 18: 0)$, triolein $(\mathrm{C} 18: 1$, cis-9), trivaccinin $(\mathrm{C} 18: 1$,

163 trans-9), trilinolein $(\mathrm{C} 18: 2$, cis-9,12) and trilinolenin $(\mathrm{C} 18: 3$, cis-9, 12, 15) differing in

164 chain length and saturation were similarly determined.

$165 \quad 2.10$ Determination of position specificity

166 Position specificity of the lipase was examined by thin-layer chromatography of the

167 reaction product obtained by using pure triolein as substrate (Sugihara et al., 1992). A

168 reaction mixture composed of $20 \mathrm{mM}$ triolein, $2 \mathrm{ml}$ of $50 \mathrm{mM}$ phosphate buffer ( $\mathrm{pH}$ 7.6),

169 and $20 \mathrm{IU}$ of the purified AML were incubated at $30^{\circ} \mathrm{C}$ for 30 min with magnetic stirring.

170 After incubation, the reaction product was extracted with $8 \mathrm{ml}$ of ethyl ether. Aliquots (10

$171 \mu \mathrm{l})$ of the ether layer were applied to a Silica Gel 60 plate (Merck KgaA, Darmstadt,

172 Germany) and developed with a 95:4:1 (v/v) mixture of chloroform, acetone, and acetic

173 acid. The spots were visualized using saturated iodine chamber and compared with

174 standards from Sigma.

$175 \quad 2.11$ Effect of various reagents and organic solvents 
The effect of various detergents, oxidizing-reducing agents, chelating agents, free

177 fatty acids, and metal ions $\left(\mathrm{Ag}^{+}, \mathrm{Co}^{2+}, \mathrm{Ni}^{2+}, \mathrm{Pb}^{2+}, \mathrm{Ca}^{2+}, \mathrm{Fe}^{3+}, \mathrm{Cu}^{2+}, \mathrm{Zn}^{2+}, \mathrm{Mg}^{2+}\right.$ and $\left.\mathrm{Hg}^{2+}\right)$

178 on purified AML activity was analyzed by incubating the pure enzyme in $1 \mathrm{mM}$ of these

179 effectors for $1 \mathrm{~h}$ at $30^{\circ} \mathrm{C}$ in $50 \mathrm{mM}$ Tris- $\mathrm{HCl}$ buffer $(\mathrm{pH}$ 8.0). The effect of urea was

180 assessed at 6.0 M. The effect of group specific reagents $(N$-acetylimidazole $(\mathrm{NAI}), N$ -

181 bromosuccinimide (NBS), phenylmethyl-sulfonylfluoride (PMSF), diethylpyrocarbonate

182 (DEPC), 1-ethyl-3-(3-dimethylaminopropyl) carbodiimide (EDAC), iodoacetate (IA),

183 citraconic anhydride (CA), phenylglyoxal (PG)) on AML was determined by incubating the

184 purified enzyme in presence of $5 \mathrm{mM}$ of these reagents for $1 \mathrm{~h}$ at $30^{\circ} \mathrm{C}$. The effect of

185 various organic solvents $(40 \%, \mathrm{v} / \mathrm{v})$ on AML activity was determined by incubating $1 \mathrm{ml}$ of

186 purified enzyme solution in $1.5 \mathrm{ml}$ of the different organic solvents in airtight vials at $30^{\circ} \mathrm{C}$,

$187200 \mathrm{rpm}$ for $24 \mathrm{~h}$. The control used was an enzyme sample without reagent/organic solvent

188 under the same experimental conditions. Residual activity was measured using the

189 spectrophotometric assay at $60^{\circ} \mathrm{C}, \mathrm{pH} 8.0$.

\section{$190 \quad 2.12$ Potential of purified AML in ester synthesis}

191 Isoamyl acetate synthesis was carried out in a stirred reactor with a capacity of $4 \mathrm{ml}$

192 in $n$-hexane using free $(0.1 \mathrm{mg})$ or immobilized AML and acetic acid as acyl donor. For

193 immobilization, $2 \mathrm{ml}$ of purified enzyme solution ( $0.1 \mathrm{mg}$ of lipase, equivalent to $78.2 \mathrm{IU}$,

194 in $10 \mathrm{mM}$ Tris- $\mathrm{HCl}$ buffer, $\mathrm{pH}$ 8.0) were mixed with $0.5 \mathrm{~g}$ of celite and the suspension was

195 stirred for $1 \mathrm{~h}$ at $4^{\circ} \mathrm{C}$. Then this suspension, containing the pure enzyme immobilized on

196 celite, was dried for $6 \mathrm{~h}$ at room temperature (GeneVac EZ-2 Plus, UK). The resulting

197 powder was suspended in $2 \mathrm{ml}$ of $n$-hexane containing $500 \mathrm{mM}$ of isoamyl alcohol. When

198 the reaction temperature reached $\left(40^{\circ} \mathrm{C}\right)$, the esterification reaction was initiated by adding 
$199300 \mathrm{mM}$ of acetic acid to the reaction mixture. The reaction mixture was incubated at $40^{\circ} \mathrm{C}$

200 for $72 \mathrm{~h}$. Control experiments were conducted in parallel without lipase under similar

201 conditions.

$202 \quad$ 2.12.1 Quantification of ester synthesis

203 Aliquots of the reaction mixture were withdrawn at definite time intervals and

204 extent of esterification monitored by a titration procedure to estimate the decrease in total

205 acid content of the reaction mixture. Titration was carried out with standardized $0.05 \mathrm{~N}$

$206 \mathrm{NaOH}$ using phenolphthalein as indicator and ethanol as a quenching agent. The accuracy

207 of the titration method was verified by gas chromatography. Isoamyl acetate concentration

208 was determined using a gas chromatography (Perkin Elmer Autosystem XL GC, USA)

209 equipped with a DB-5 column (30 m length, $0.25 \mathrm{~mm}$ i.d., $0.25 \mu \mathrm{m}$ film thickness) and a

210 flame ionization detector. Nitrogen was used as a carrier gas with a flow rate of $1 \mathrm{ml} / \mathrm{min}$.

211 The temperatures of the column oven, the injection port and the detector were maintained at

21260,250 and $200^{\circ} \mathrm{C}$, respectively. The conversion percentage calculated by both GC analysis

213 (which showed product formation) and titrimetry (which showed acid consumption) were

214 in good agreement.

\section{3. Results}

\section{$216 \quad 3.1$ Lipase purification}

217 The isolation of the enzyme from the culture filtrate was achieved by a three-step

218 procedure. The lipase from crude filtrate was precipitated by ammonium sulphate at $40 \%$

219 saturation. The precipitated enzyme was dissolved in a minimum volume of $10 \mathrm{mM}$ Tris-

$220 \mathrm{HCl}$ buffer, $\mathrm{pH}$ 8.0. The first step of precipitation and dialysis resulted in $92.52 \%$ overall

221 yield with specific activity of $3.66 \mathrm{IU} / \mathrm{mg}$. The first chromatographic step of anion 
222 exchange (Q Sepharose HP column) separated $p$-NPP hydrolyzing enzyme from a part of

223 contaminating proteins. In addition, column chromatography on Toyopearl Phenyl-650M

224 was required for the isolation of the enzyme, which resulted in a single peak of active

225 protein and in an electrophoretically homogeneous preparation (Fig. 1a). By this

226 purification procedure a 398-fold increase in enzyme specific activity was achieved, with

227 an overall yield of $36 \%$ (Table 1). The pure enzyme preparations were stored at $-20^{\circ} \mathrm{C}$ and

228 were used to study its properties.

\section{$229 \quad 3.2$ Gel electrophoresis and zymography}

230 SDS-PAGE of purified lipase showed single protein band of a relative molecular

231 mass of $33 \mathrm{kDa}$. The activity of the band on the gel was detected using MUF-butyrate in

232 situ enzyme assay after SDS-PAGE and the $p$-NPP hydrolyzing activity coincided with the 233 purified protein ((Fig. 1b).

\section{$2343.3 \mathrm{~N}$-terminal sequence of AML}

$235 \quad$ N-terminal sequencing of the PVDF transferred band from an electrophoretic gel

236 allowed the identification of 20 amino acid residues: AANPYERGPDPTTASIEATR. This

237 sequence was compared with the sequences of known lipases (Table 2). It exhibited

238 significant similarity (85\%) only with the N-terminal sequence of Streptomyces exfoliatus

239 lipase (Wei et al. 1998). Also, the first 19 amino acids of AML were found to be identical

240 to 48-66 amino acids of a putative lipase identified from an ORF in recently completed

241 genome sequence of A. mediterranei U32 (genebank accession no. ADJ49206).

\section{$242 \quad 3.4$ The effect of $\mathbf{p H}$ and temperature on activity and stability}

243 The purified enzyme was most active toward $p$-NPP at $\mathrm{pH}$ 8.0. The activity was not 244 much affected at $\mathrm{pH} 7$ and 9 where it showed around $90 \%$ of relative activity. The purified 
245 enzyme was stable in the $\mathrm{pH}$ range 6-9 retaining more than $95 \%$ of relative activity after 24

$246 \mathrm{~h}$ of incubation (data not shown). The purified enzyme exhibited maximum activity toward

$247 p$-NPP at $60^{\circ} \mathrm{C}$. Above this temperature sharp inactivation occurred (data not shown).

\section{3.5 Determination of kinetic constants}

249 The kinetic analysis of purified AML performed on standard assay substrate, $p$-NPP 250 at $60^{\circ} \mathrm{C}$ produced a Lineweaver Burk plot corroborating the Michaelis-Menten behavior of

251 the enzyme with a $V_{\max }^{a p p}$ of $2.53 \pm 0.06 \mathrm{mmol} / \mathrm{min} \mathrm{mg,} K_{m}^{a p p}$ of $0.10 \pm 0.01 \mathrm{mM}$ and $k_{c a t}^{a p p}$ of $2521467.59 \pm 34.86 / \mathrm{s}$.

$253 \quad 3.6$ Substrate range

254 The enzyme substrate range was studied with $p$-nitrophenyl esters of varying fatty 255 acyl chain lengths. The highest hydrolysis rates were obtained with $p$-NP caprylate (C8:0)

256 followed by $p$-NP caproate (C6:0), indicating the enzyme's preference for medium-size

257 acyl chain lengths (Fig. 2a). Relative activity for each substrate is expressed as a percentage

258 of that for $p$-NP caprylate (C:8). The substrate preferences of AML were characterized

259 with various oil and triacylglycerol substrates. As shown in Figs. $2 \mathrm{~b}$ and $2 \mathrm{c}$, relative

260 activity for each substrate is expressed as the percentage of that for olive oil. AML showed

261 relatively high activity using various emulsified oils especially for olive oil. Among the

262 substrates tested, AML showed a distinct preference for long, unsaturated fatty acyl chains.

263 The relative activities for substrates with cis-9 unsaturation (C18:1, cis-9; C18:2, cis-9, 12;

$264 \mathrm{C} 18: 3$, cis-9, 12, 15) are higher than the relative activity on the saturated triacylglycerols

265 (C8:0, C16:0, C18:0).

$266 \quad 3.7$ Position specificity 
In order to determine the position specificity (regio-selectivity) of purified AML, 268 thin-layer chromatography of AML catalyzed hydrolysis products of pure triolein was 269 performed (Fig. 3). After $30 \mathrm{~min}$ at $30^{\circ} \mathrm{C}$, the products of hydrolytic action of purified 270 AML on triolein were oleic acid (major product), 1,3-dioleylglycerol (1,3-DO), 1,2(2,3)-

271 dioleylglycerol (1,2(2,3)-DO) and 1(2)-monooleylglycerol (1(2)-MO) (minor products).

272 From observation of reaction products, AML did not discriminate between $s n-1$ and $s n-2$ 273 positions of triolein.

$274 \quad 3.8$ Effect of various reagents and organic solvents

275 Various compounds were studied for their effect on purified AML activity (Table

276 3). AML proved to be insensitive to the chelating agents, ethylenediaminetetraacetic acid 277 (EDTA) and sodium citrate. It showed relative insensitivity to SDS, but incubation with 1 $278 \mathrm{mM}$ digitonin and sodium deoxycholate caused pronounced activation of the enzyme by $27942.5 \%$ and $141.3 \%$, respectively. The enzyme was activated in $1 \mathrm{mM} \mathrm{1,4-dithiothreitol,} \beta$ 280 mercaptoethanol and ascorbic acid by $47.6 \%, 36.4 \%$ and $24.4 \%$, respectively. The 281 incubation with $1 \mathrm{mM}$ of different chain length fatty acids had little effect on the enzyme 282 activity. Significant stability was observed toward metal ions except $\mathrm{Hg}^{2+}$, which showed 283 the highest reduction in AML activity by $83.3 \%$ (data not shown). AML was not inhibited 284 by NAI, CA, IA and PG suggesting the non-involvement of tyrosine, lysine, cystein and 285 arginine residues in catalysis. Strong inhibition of enzyme by PMSF, EDAC, DEPC and 286 NBS was observed which indicated the significant involvement of serine, carboxylate, 287 histidine and tryptophan for catalytic activity (Table 4). Purified AML was stable in the 288 presence of water-miscible solvents (dimethyformamide, methanol, ethanol and 2289 propanol) as well as water-immiscible solvents ( $n$-hexane, $p$-xylene, cyclohexene and 
290 toluene). In most cases the enzyme was significantly activated, with residual activities

291 greater than $100 \%$ (data not shown).

\section{$292 \quad 3.9$ Potential of purified AML in ester synthesis}

293 Purified AML, free and celite-immobilized, was used to catalyze the esterification

294 of isoamyl alcohol to isoamyl acetate in $n$-hexane using acetic acid as an acyl donor. AML

295 exhibited significant potential for synthesis of isoamyl acetate. After $72 \mathrm{~h}$ of reaction a

296 yield of isoamyl acetate of $34.4 \%$ and $16.2 \%$, with respect to the initial acetic acid, was

297 obtained using immobilized and free AML, respectively (Fig. 4).

\section{4. Discussion}

299 The number of commercially available lipases has increased considerably in recent

300 decades, along with the demand for these biocatalysts. The characterization of new lipolytic

301 enzymes, the development of new purification procedures and the increased number of

302 studies on the subject, mainly on lipases of microbial origin, are all factors that contribute

303 to the novel biotechnological applications of these enzymes (Silva et al., 2009). Lipolytic

304 enzymes are subdivided into different groups including carboxylesterases, lipases and sterol

305 esterases. Some of these enzymes show very wide substrate specificity and it is not always

306 possible to identify the group to which they belong (Calero-Rueda et al., 2002). The

307 purified AML showed activity towards different esters including $p$-NPB (a generic

308 substrate for esterase activity), $p$-NPP (a generic substrate for lipase activity) and triolein (a

309 substrate for detection of true lipase activity). Purified AML seemed to exhibit both an

310 esterase and a true lipase activity as previously reported in the case of Streptomyces

311 coelicolor hydrolase (Bielen et al., 2009) and Streptomyces cinnamomeus Tü89 lipase

312 (Sommer et al., 1997). 
In the present investigation, electrophoretically homogeneous AML was purified

314 using ammonium sulphate precipitation followed by anion exchange and hydrophobic

315 interaction chromatography. Hydrophobic interaction chromatography has been used for

316 purification of many lipases since these enzymes are hydrophobic and display strong

317 interaction with hydrophobic supports (Sharma et al., 2001). Queiroz et al. (1995) used

$31820 \%$ of the ammonium sulphate in the eluent and observed total retention of lipase on a

319 hydrophobic column. We also observed $100 \%$ retention of the enzyme on Toyopearl

320 Phenyl-650M column in presence of $20 \%$ ammonium sulphate. Isopropanol at 30\% (v/v)

321 was required to elute the homogeneous AML from the hydrophobic interaction column

322 with a final yield of $36 \%$, which is a higher yield compared to the only reported purification

323 of a native actinomycete lipase (Abramić et al., 1999). Similar solvent conditions were

324 employed for the elution of bacterial lipases (Kordel et al., 1991; Zhang et al., 2002). In

325 aqueous solutions (including buffers and salts), the purified AML formed aggregates. Gel

326 filtration chromatography of AML at low protein concentration showed elution in the void

327 volume, indicating that AML formed active molecular aggregates (data not shown). The

328 aggregation tendency of lipolytic enzymes is well documented in the literature (Castro-

329 Ochoa et al., 2005; Lima et al., 2004). The presence of aggregates has been reported for

330 other enzymes with lipase activity, and may be explained by the strong hydrophobic

331 character of these enzymes (Castro-Ochoa et al., 2005).

332 The denatured molecular mass of $33 \mathrm{kDa}$ of AML is in the range reported for other

333 enzymes with lipolytic activity (20-60 kDa) (Gupta et al., 2004). The extracellular lipase

334 reported here is different to the thermophilic lipases characterized from other actinomycete

335 strains, which showed lower molecular mass (23.9-28.5 kDa) and thermostability (Abramić 
et al., 1999; Côté and Shareck, 2008; Zhang et al., 2008). However, the purified AML

337 showed significant N-terminal sequence homology to S. exfoliatus lipase. S. exfoliatus

338 lipase is the only lipase from the Streptomyces genus whose crystal structure has been

339 determined (Wei et al., 1998). However, its biochemical characterization and chain length

340 specificity has not been reported. Therefore, comparison between these two enzymes is not

341 yet possible.

342 The high activity and stability of AML over a wide $\mathrm{pH}$ range (5-9) suggests its

343 usefulness in a range of industrial applications. In different industrial applications

344 thermostability is an important property for applications in processes operating at high

345 temperatures (Nawani and Kaur, 2007; Sharma et al., 2002). Thus, the high activity and

346 stability of AML $\left(50-60^{\circ} \mathrm{C}\right)$ makes it potentially useful in biocatalytic processes operating

347 at high temperatures. The purified AML showed low $K_{m}^{a p p}$ value $(0.10 \pm 0.01 \mathrm{mM})$ and

348 high $V_{\max }^{a p p}$ value $(2.53 \pm 0.06 \mathrm{mmol} / \mathrm{min} \mathrm{mg})$ indicating high affinity between enzyme and

349 substrate and higher catalytic efficiency (Sharma et al., 2001).

350 AML showed highest hydrolytic activity with $p$-NP caprylate, indicating its clear

351 preference for saturated medium acyl chain lengths as previously reported for other

352 bacterial lipases (Abramić et al., 1999; Schmidt-Dannert et al., 1996; Soliman et al., 2007).

353 AML showed relatively high activity using various emulsified oils, particularly olive oil,

354 which could be due to its high content of long, unsaturated fatty acyl chains, such as oleic

355 acid. These results highlight AML could play an important role in applications such as

356 removal of oil spills in the environment (Hasan et al., 2006). It could be used in biodiesel

357 production due to its ability to hydrolyze a wide range of oils (Tan et al., 2010) coupled 
with stability in polar solvents. Interestingly AML also showed distinct specificity for long, unsaturated fatty acyl chains, which is a very valuable property for enzymatic restructuring by interesterification of fats and oils with unsaturated fatty acids to improve the physical

361 properties of triglycerides for use in food industries (Jackson et al., 1997). In order to determine the position specificity of AML, pure triolein hydrolysis

363 products were analyzed using thin-layer chromatography (Fig. 3). The hydrolysis products

364 by AML were oleic acid (major product), 1,3-DO, 1,2(2,3)-DO and 1(2)-MO (minor

365 products). Spontaneous acyl migration was considered unlikely because of the short

366 reaction time. Like the majority of bacterial lipases (Leščić et al., 2001; Rahman et al.,

367 2005), AML belongs to the group of nonspecific lipases which are able to hydrolyze both

368 primary and secondary ester bonds in triolein.

Many biotechnological processes involve the presence in the reaction media of

370 certain ions that could act as modifiers of the enzyme activity. To test this possibility, the

371 influence of different metal ions and several putative inhibitors or compounds commonly

372 used was assayed on the purified AML. Among the different metal ions tested, only $\mathrm{Hg}^{2+}$

373 strongly inhibited AML activity probably due to the binding of $\mathrm{Hg}^{2+}$ to a functional thiol

374 group (Patkar and Björkling, 1994). Other commonly used effector molecules were tested

375 to evaluate their capacity to inhibit or activate the purified AML (Table 3). Urea causes

376 disaggregation of the enzymes and does not produce a significant inhibition of activity at

377 concentrations below 6.0 M (Bofill et al., 2010). AML was only marginally affected in 6.0

378 M urea. The pure enzyme was significantly stable in presence of SDS as reported earlier

379 (Soliman et al., 2007; Yu et al., 2009). Detergents, digitonin and sodium deoxycholate,

380 markedly activated the enzyme which is in contrast with their effect on a thermostable 
381 lipase from Burkholderia cepacia ATCC 25416 (Wang et al., 2009). Besides direct

382 activation or inactivation, detergents may alter the hydrophobicity of the enzyme; affect

383 micelle formation and the ratio of free-to-micellar substrate (Helistö and Korpela, 1998).

384 Reducing agents often cause inhibition of lipase activity (Sharma et al., 2002; Soliman et

385 al., 2007). In contrast, AML was strongly activated by these reducing reagents. A similar

386 activating effect of reducing agents was observed for G. thermoleovorans $\mathrm{YN}$ lipase

387 (Soliman et al., 2007). The presence of fatty acids caused slight inhibition; this is consistent

388 with a competition for the catalytic centre. Such inhibition is in agreement with results

389 obtained for other lipases (Ruiz et al., 2004).

390 The triad of Ser-His-Asp is observed in catalytic sites of several lipases with

391 carboxylate residue of either aspartic acid or glutamic acid (Schrag et al., 1991). In the

392 present study, chemical modification was employed to determine the amino acids

393 responsible for AML catalysis. The amino acids in the catalytic triad of lipases have

394 previously been determined through chemical modification studies (Hilton and Buckley,

395 1991; Mhetras et al., 2009). The catalytic site in the purified AML involved Ser, His and

396 carboxylate residues. In addition, Trp seemed to play an important role in catalytic activity

397 of AML since the NBS mediated modification resulted in significant inactivation. Trp has

398 been shown to be responsible for interfacial activation (Feng et al., 2002) and may possibly

399 serve the same function in AML catalysis.

400 The stability or enhancement of activity in the presence of organic solvents is

401 generally considered a desirable feature, as it is a prerequisite for synthetic applications in

402 non-aqueous media (Dandavate et al., 2009; Zaks and Klibanov, 1998). AML was

403 remarkably stable with activation in both hydrophilic and hydrophobic organic solvents. 
404 Stability of bacterial lipases in hydrophilic solvents with activation is a rare property (Lima

405 et al., 2004), although stability in hydrophilic solvents has been reported in few

406 actinomycete lipases (Bielen et al., 2009; Leščić et al., 2001).

407 Isoamyl acetate is one of the most important flavor and fragrance compounds used

408 in the food, beverage, cosmetics and pharmaceutical industries because of its characteristic

409 banana flavour (Romero et al., 2005). AML exhibited significant potential for the synthesis

410 of isoamyl acetate. Although, the reaction conditions were not optimized, the purified

411 lipase showed considerable esterification capacity (34.4\%). Furthermore, lipase

412 immobilized on celite exhibited roughly 2 fold higher esterification for isoamyl acetate

413 synthesis in comparison to free enzyme (Fig. 4). The immobilization of lipases on celite has

414 been previously reported to improve the catalytic activity of enzymes by providing

415 protection against the denaturing effects of organic solvents (Khare and Nakajima, 2000;

416 Salah et al., 2007).

\section{5. Conclusions}

418 In this study, AML was purified to homogeneity with 398 fold purity and a specific

419 activity of $781 \mathrm{IU} / \mathrm{mg}$ protein. The characterization study of purified AML showed that it

420 has a number of industrially important characteristics like high thermostability, organic

421 solvent tolerance and specificity towards broad substrate range. All these features make

422 AML, a suitable candidate for application in non aqueous biocatalytic processes such as

423 esterification of primary and secondary alcohols, random interesterification of different oils

424 and fats, oil contaminated biodegradation and biodiesel production. Moreover, purified

425 AML also showed potential in synthesis of industrially important flavor ester, isoamyl 
acetate. Therefore, future studies should focus on optimization of isoamyl acetate synthesis

427 using AML and examination of related synthetic capabilities.

428 Acknowledgements

This work was financially supported by DIT ABBEST Research Scholarship (PB

431 Synthesis and Chemical Biology (CSCB), University College Dublin, Dublin, for technical 432 assistance with gas chromatography.

\section{References}

434 Abramić, M., Leščić, I., Korica, T., Vitale, L., Saenger, W., Pigac, J., 1999. Purification and properties of extracellular lipase from Streptomyces rimosus. Enzyme Microb. Technol. 25, 522-529.

437 Berekaa, M.M., Zaghloul, T.I., Abdel-Fattah, Y.R., Saeed, H.M., Sifour, M., 2009. Purification of a novel glycerol-inducible lipase from thermophilic Geobacillus stearothermophilus strain-5. World J. Microbiol. Biotechnol. 25, 287-294. SGNH hydrolase of Streptomyces coelicolor has (aryl)esterase and a true lipase activity. Biochimie 91, 390-400.

Bofill, C., Prim, N., Mormeneo, M., Manresa, A., Javier Pastor, F.I., Diaz, P., 2010. Differential behaviour of Pseudomonas sp. 42A2 LipC, a lipase showing greater versatility than its counterpart LipA. Biochimie 92, 307-316.

Bradford, M.M., 1976. A rapid and sensitive method for the quantitation of microgram quantities of protein utilizing the principle of protein-dye binding. Anal. Biochem. $72,248-254$. 
Burkert, J.F.M., Maugeri, F., Rodrigues, M.I., 2004. Optimization of extracellular lipase production by Geotrichum sp. using factorial design. Bioresour. Technol. 91, 7784.

452 Calero-Rueda, O., Plou, F.J., Ballesteros, A., Martinez, A.T., Martinez, M.J. 2002. Production, isolation and characterization of a sterol esterase from Ophiostoma piceae. Biochim. Biophys. Acta. 1599, 28-35.

Castro-Ochoa, L.D., Rodriguez-Gomez, C., Valerio-Alfaro, G., Ros, R.O. 2005.

Côté, A., Shareck, F., 2008. Cloning, purification and characterization of two lipases from Streptomyces coelicolor A3(2). Enzyme Microb. Technol. 42, 381-388.

Dandavate, V., Jinjala, J., Keharia, H., Madamwar, D., 2009. Production, partial purification and characterization of organic solvent tolerant lipase from Burkholderia multivorans V2 and its application for ester synthesis. Bioresour. Technol. 100, 3374-3381.

Dheeman, D.S., Frias, J.M., Henehan, G.T.M., 2010. Influence of cultivation conditions on the production of a thermostable extracellular lipase from Amycolatopsis mediterranei DSM 43304. J. Ind. Microbiol. Biotechnol. 37, 1-17.

Feng, J., Wehbi, H., Roberts, M.F. 2002. Role of tryptophan residues in interfacial binding of phosphatidylinositol-specific phospholipase C. J. Biol. Chem. 277, 19867-19875. 
471 Gupta, R., Gupta, N., Rathi, P., 2004. Bacterial lipases: an overview of production, 472 purification and biochemical properties. Appl. Microbiol. Biotechnol. 64, 763-781.

473 Hasan, F., Shah, A., Hameed, A., 2006. Industrial application of microbial lipases.

$474 \quad$ Enzyme Microb. Technol. 39, 235-251.

475 Helistö, P., Korpela, T., 1998. Effects of detergents on activity of microbial lipases as

476 measured by the nitrophenyl alkanoate esters method. Enzyme Microb. Technol. 23, $477 \quad 113-117$.

478 Hilton, S., Buckley, J.T., 1991. Studies on the reaction mechanism of a microbial

479 lipase/acyltransferase using chemical modification and site-directed mutagenesis. J.

480 Biol. Chem. 266, 997-1000.

481 Jackson, M.A., King, J.W., List, G.R., Neff, W.E., 1997. Lipase-catalyzed randomization 482 of fats and oils in flowing supercritical carbon dioxide. J. Am. Oil Chem. Soc. 74, $483 \quad 635-639$.

484 Khare, S.K., Nakajima, M., 2000. Immobilization of Rhizopus japonicus lipase on celite 485 and its application for enrichment of docosahexaenoic acid in soybean oil. Food $486 \quad$ Chem. 68, 153-157.

487 Kordel, M., Hofmann, B., Schomburg, D., Schmid, R.D., 1991. Extracellular lipase of 488 Pseudomonas sp. strain ATCC 21808: purification, characterization, crystallization, 489 and preliminary X-ray diffraction data. J. Bacteriol. 173, 4836-4841.

490 Lee, D.W., Kim, H.K., Lee, K.W., Kim, B.C., Choe, A.C., Lee, H.S., Kim, D.S., Pyun, 491 Y.R., 2001. Purification and characterization of two distinct thermostable lipases 492 from the gram-positive thermophilic bacterium Bacillus thermoleovorans ID-1. $493 \quad$ Enzyme Microb. Technol. 29, 363-371. 
Leščić, I., Vukelic, B., Majeric-Elenkov, M., Saenger, W., Abramić, M., 2001. Substrate specificity and effects of water-miscible solvents on the activity and stability of extracellular lipase from Streptomyces rimosus. Enzyme Microb. Technol. 29, 548553.

Lima, V.M.G., Krieger, N., Mitchell, D.A., Baratti, J.C., Filippis, I., Fontana, J.D., 2004. Evaluation of the potential for use in biocatalysis of a lipase from a wild strain of Bacillus megaterium. J. Mol. Catal. B: Enzym. 31, 53-61.

Mhetras, N.C., Bastawde, K.B., Gokhale, D.V., 2009. Purification and characterization of acidic lipase from Aspergillus niger NCIM 1207. Bioresour. Technol. 100, 14861490.

Nawani, N., Kaur, J., 2007. Studies on lipolytic isoenzymes from a thermophilic Bacillus sp.: production, purification and biochemical characterization. Enzyme Microb. Technol. 40, 881-887.

Pandey, A., Benjamin, S., Soccol, C.R., Nigam, P., Krieger, N., Soccol, V.T., 1999. The realm of microbial lipases in biotechnology. Biotechnol. Appl. Biochem. 29, 119131.

Patkar, S., Björkling, F., 1994. Lipase inhibitors, in: Woolley, P., Petersen, S.B. (Eds.), Lipases: their structure, biochemistry and application. Cambridge University Press, pp. $207-224$.

Prim, N., Sanchez, M., Ruiz, C., Pastor, F.I., Diaz, P., 2003. Use of methylumbeliferyl515 derivative substrates for lipase activity characterization. J. Mol. Catal. B: Enzym. 515 $22,339-346$. 
516 Queiroz, J.A., Garcia, F.A.P., Cabral, J.M.S., 1995. Hydrophobic interaction

517 chromatography of Chromobacterium viscosum lipase. J. Chromatogr. A 707, 137-

$518 \quad 142$.

519 Rahman, R.N.Z.R.A., Baharum, S.N., Basri, M., Salleh, A.B., 2005. High-yield

$520 \quad$ purification of an organic solvent-tolerant lipase from Pseudomonas sp. strain S5.

$521 \quad$ Anal. Biochem. 341, 267-274.

522 Romero, M.D., Calvo, L., Alba, C., Daneshfar, A., Ghaziaskar, H.S. 2005. Enzymatic

523 synthesis of isoamyl acetate with immobilized Candida antarctica lipase in n-

524 hexane. Enzyme Microb. Technol. 37, 42-48.

525 Ruiz, C., Falcocchio, S., Xoxi, E., Pastor, F.I.J., Diaz, P., Saso, L., 2004. Activation and

526 inhibition of Candida rugosa and Bacillus-related lipases by saturated fatty acids

527 evaluated by a new colorimetric microassay. Biochim. Biophys. Acta. 1672, 184-

528191.

529 Salah, R.B., Ghamghui, H., Miled, N., Mejdoub, H., Gargouri, Y., 2007. Production of

530 butyl acetate ester by lipase from novel strain of Rhizopus oryzae. J. Biosci. Bioeng.

$531 \quad 103,368-372$.

532 Salameh, M.A., Wiegel, J., 2007. Purification and characterization of two highly

533 thermophilic alkaline lipases from Thermosyntropha lipolytica. Appl. Environ.

$534 \quad$ Microbiol. 73, 7725-7731.

535 Schmidt-Dannert, C., Rua, M.L., Atomi, H., Schmid, R.D., 1996. Thermoalkalophilic

536 lipase of Bacillus thermocatenulatus I. Molecular cloning, nucleotide sequence,

537 purification and some properties. Biochim. Biophys. Acta. 1301, 105-114. 
Schrag, J.D., Li, Y., Wu, S., Cygler, M., 1991. Ser-His-Glu triad forms the catalytic site of the lipase from Geotrichum candidum. Nature 351, 761-764.

540 Sharma, R., Soni, S.K., Vohra, R.M., Gupta, L.K., Gupta, J.K., 2002. Purification and 541 characterization of a thermostable alkaline lipase from a new thermophilic Bacillus sp. RSJ-1. Process Biochem. 37, 1075-1084.

Sharma, R.,Chisti, Y., Banerjee, U.C., 2001. Production, purification, characterization, and applications of lipases. Biotechnol. Adv. 19, 627-662.

Silva, W.O.B., Santi, L., Berger, M., Pinto, A.F.M., Guimaraes, J.A., Schrank, A., Vainstein, M.H., 2009. Characterization of a spore surface lipase from the biocontrol agent Metarhizium anisopliae. Process Biochem. 44, 829-834.

Soliman, N.A., Knoll, M., Abdel-Fattah, Y.R., Schmid, R.D., Lange, S., 2007. Molecular cloning and characterization of thermostable esterase and lipase from Geobacillus thermoleovorans YN isolated from desert soil in Egypt. Process Biochem. 42, $1090-1100$.

Sommer, P., Bormann, C., Gotz, F., 1997. Genetic and biochemical characterization of a new extracellular lipase from Streptomyces cinnamomeus. Appl. Environ. Microbiol. 63, 3553-3560.

Sugihara, A., Ueshima, M., Shimada, Y., Tsunasawa, S., Tominaga, Y., 1992.

558 Sztajer, H., Maliszewska, I., Wierczorek, J., 1988. Production of exogenous lipases by 559 bacteria, fungi, and actinomycetes. Enzyme Microb. Technol. 10, 492-497. 
Tan, T., Lu, J., Nie, K., Deng, L., Wang, F., 2010. Biodiesel production with immobilized lipase: A review. Biotech. Adv. 28, 628-634.

562 Wang, X., Yu, X., Xu, Y., 2009. Homologous expression, purification and characterization of a novel high-alkaline and thermal stable lipase from Burkholderia cepacia ATCC 25416. Enzyme Microb. Technol. 45, 94-102.

Wei, Y., Swenson, L., Castro, C., Derewenda, U., Minor, W., Arai, H., Aoki, J., Inoue, K., Servin-Gonzalez, L., Derewenda, Z.S., 1998. Structure of a microbial exfoliatus lipase at $1.9 \AA$ resolution. Structure, 6, 511-519.

569 Winkler, U.K., Stuckman. M., 1979. Glycogen, hyaluronate and some other polysaccharides greatly enhance the formation of exolipase by Serratia marcescens.

572 Yu, L., Xu, Y., Yu, X., 2009. Purification and properties of a highly enantioselective Lmenthyl acetate hydrolase from Burkholderia cepacia. J. Mol. Catal. B:Enzym. 57,

575 Zaks, A., Klibanov, A.M., 1998. Enzymatic catalysis in nonaqueous solvents. J. Bio. Chem. 263, 3194-3201.

577 Zhang, J., Hou, Z., Yao, C., Yu, J., 2002. Purification and properties of lipase from a 578 Bacillus strain for catalytic resolution of (R)-naproxen. J. Mol. Catal. B:Enzym. 18,

580 Zhang, Y., Meg, K., Wang, Y., Luo, H., Yang, P., Shi, P., Wu, N., Fan, Y., Li, J., Yao, B., 581 2008. A novel proteolysis-resistant lipase from keratinolytic Streptomyces fradiae 582 var. k11. Enzyme Microb. Technol. 42, 346-352. 


\section{Table 1}

584 Purification of AML

\begin{tabular}{|c|c|c|c|c|c|}
\hline Purification step & Total activity $^{\mathrm{a}}$ & Total protein ${ }^{\mathrm{b}}$ & Specific activity & Purification & Yield \\
\hline & (IU) & $(\mathrm{mg})$ & (IU/mg) & (fold) & $(\%)$ \\
\hline$\overline{\text { Culture filtrate }}$ & 212.0 & 108.0 & 1.96 & 1.00 & 100 \\
\hline Ammonium sulphate precipitation & 196.16 & 27.34 & 7.17 & 3.66 & 92.52 \\
\hline Q Sepharose HP & 115.82 & 4.96 & 23.35 & 11.91 & 54.63 \\
\hline Toyopearl Phenyl-650M & 76.6 & 0.098 & 781.63 & 398.79 & 36.13 \\
\hline
\end{tabular}

$591 \quad{ }^{a}$ One International Unit (IU): $1 \mu \mathrm{mol}$ of $p$-NP released per min using $p$-NPP as substrate.

$592{ }^{\mathrm{b}}$ Protein concentration was estimated by Bradford method (Bradford 1979).

593

594

595

596

597 
598 Table 2

599 N-terminal sequence comparison of AML with Streptomyces exfoliatus lipase

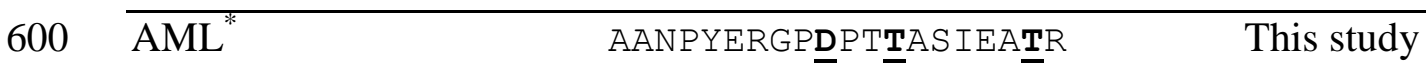

601 S. exfoliatus lipase AANPYERgPAPTNASIEASR $\quad$ (Wei et al. 1998)

602 *Non-matching amino acid residues are underlined and highlighted in bold.

603

604

605

606

607

608

609

610

611

612

613

614

615

616

617

618

619

620 


\section{Table 3}

622 Effect of effector molecules on AML activity

623 Effector molecule $\quad$ Relative activity $(\% \pm \text { SD })^{\mathrm{a}}$

624 Control

$100.0 \pm 1.8$

625 EDTA

$99.1 \pm 2.5$

626 Sodium citrate

$99.5 \pm 3.8$

627 SDS

$99.7 \pm 1.5$

628 Digitonin

$142.5 \pm 2.4$

629 Sodium deoxycholate

$241.3 \pm 1.0$

$630 \quad \beta$-Mercaptoethanol

$136.4 \pm 2.2$

631 1,4-Dithiothreitol

$147.6 \pm 0.9$

632 Ascorbic acid

$124.4 \pm 3.4$

633 Capric acid

$89.7 \pm 0.5$

634 Myristic acid

$97.1 \pm 1.9$

635 Palmitic acid

$99.6 \pm 1.4$

636 Urea $(6.0 \mathrm{M})^{\mathrm{b}}$

$98.9 \pm 3.5$

$637{ }^{a}$ Purified AML was incubated in the presence of effector molecules $(1 \mathrm{mM})$ at $30^{\circ} \mathrm{C}$ for $1 \mathrm{~h}$. The

638 activity is expressed as a percentage of the activity of untreated control. Values represent the

639 mean of three replicates \pm standard deviation (SD).

$640{ }^{\mathrm{b}}$ Urea concentration in incubation mixture. 


\section{Table 4}

645 Effect of group specific reagents on AML activity

\begin{tabular}{llll}
\cline { 2 - 4 } 646 & Reagent & Possible reaction site & Residual activity $(\% \pm$ SD) \\
\cline { 2 - 4 } 647 & CA & Lys & $98.8 \pm 3.2$ \\
648 & DEPC & His & 00.0 \\
649 & EDAC & Asx/Glx & 00.0 \\
650 & IA & Cys & $92.3 \pm 3.1$ \\
651 & NAI & Tyr & $99.2 \pm 2.7$ \\
652 & NBS & Trp & $34.4 \pm 1.5$ \\
653 & PG & Arg & $99.5 \pm 1.2$ \\
654 & PMSF & Ser & $11.6 \pm 1.8$
\end{tabular}

655 Purified AML (10 $\mu \mathrm{g})$ was incubated with reagents $(5 \mathrm{mM})$ specific to different amino acid

656 functional groups. After $1 \mathrm{~h}$ at $30^{\circ} \mathrm{C}$, residual AML activity was determined. The activity is

657 expressed as a percentage of the activity of untreated control. Values represent the mean of three

658 replicates \pm standard deviation $(\mathrm{SD})$.

659

660

661

662

663

664

665

666 
668 Fig. 1 SDS-PAGE of purified AML and zymogram analysis

669 (a) Lane 1: standard proteins; lane 2: culture supernatant; lane 3: culture supernatant precipitated 670 with $40 \%$ ammonium sulphate and dialyzed; lane 4: purified protein after Toyopearl Phenyl-

$671650 \mathrm{M}$ chromatography. (b) Zymogram from an SDS-PAGE of purified AML analyzed for

672 activity by MUF-butyrate (right) and subsequently stained with silver nitrate (left). The samples

673 loaded correspond to molecular weight standards (lane 1) and purified AML (lanes 2 and 3).

674 Fig. 2 Relative activities of AML towards various substrates

675 Lipase activities are expressed as the percentage of that of $p$-NP caprylate (C:8) (a) or olive oil (b 676 and c). Values represent the mean of three independent experiments and error bars indicate 677 standard deviations.

678 Fig. 3 Thin-layer chromatography of products of triolein hydrolysis by AML

679 Lane 1: 1(2)-monooleylglycerol (1(2)-MO); lane 2: oleic acid; lane 3: 1,2(2,3)-dioleylglycerol

680 (1,2(2,3)-DO) with traces of 1,3-dioleylglycerol; lane 4: 1,3-dioleylglycerol (1,3-DO); lane 5:

681 triacylglycerol (TO); lane 6: standard mixture; lane 7: control (without enzyme); lane 8: 20 IU of 682 purified AML.

683 Fig. 4 Isoamyl acetate synthesis by free (•) and celite-immobilized (०) AML

684 Values represent the means of three independent experiments and error bars indicate standard 685 deviations. 
$690 \quad$ Fig. 1

691

(a)

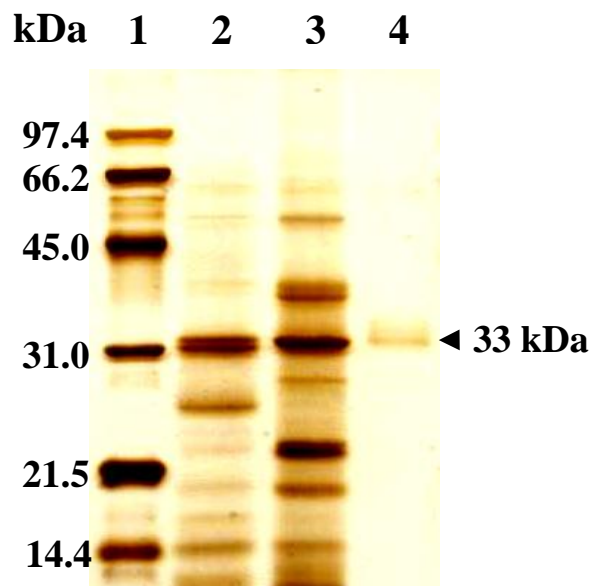

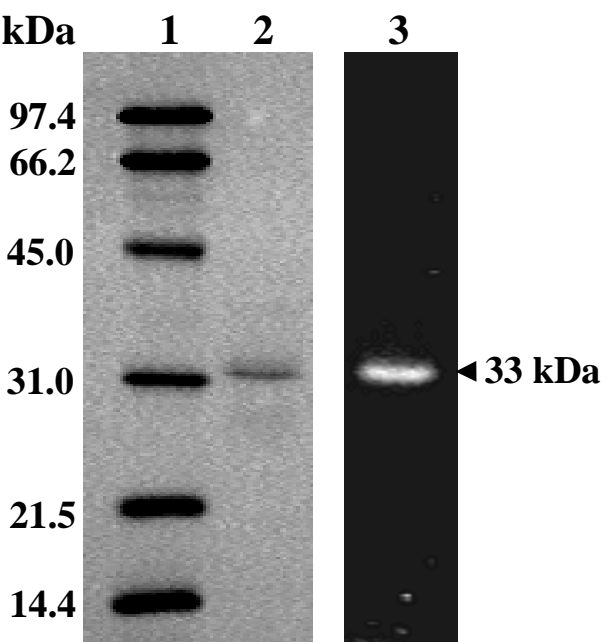

693

694

695

696

697

698

699

700

701

702

703

704

705

706 
Fig. 2
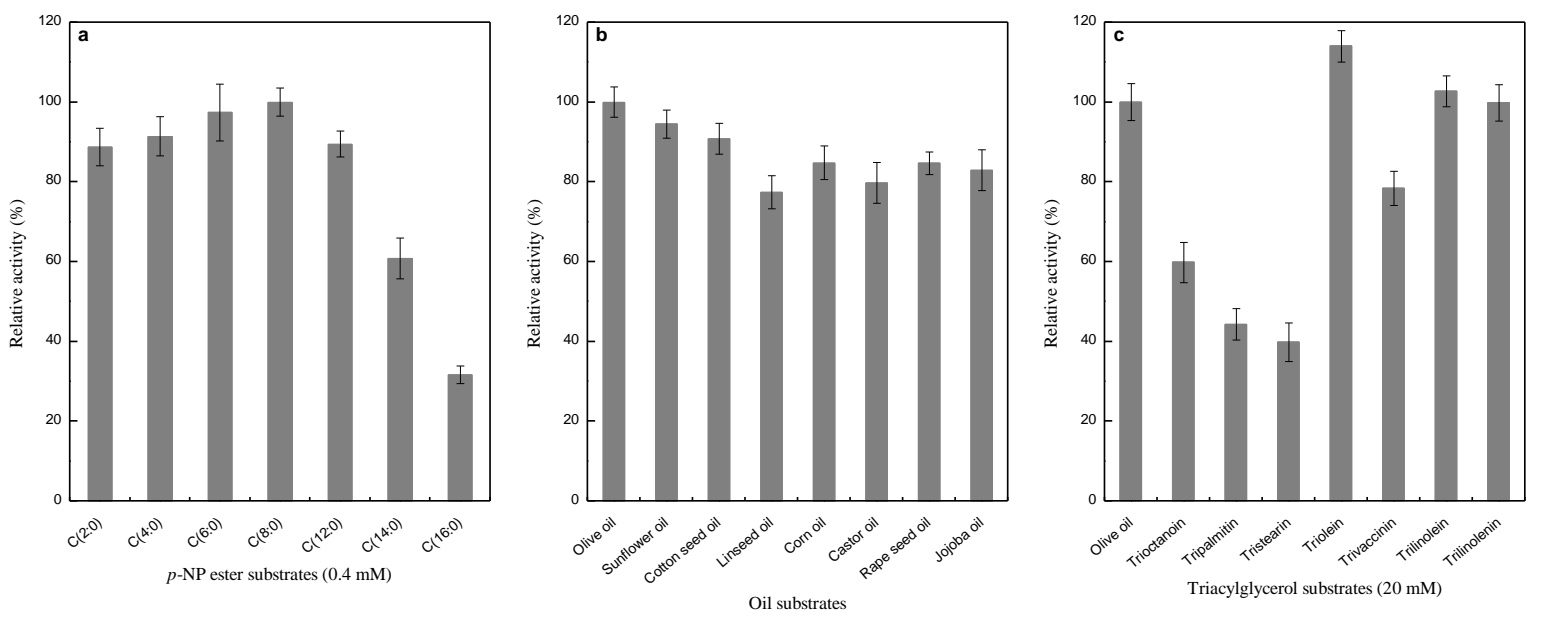

708

709

710

711

712

713

714

715

716

717

718

719

720

721 
$722 \quad$ Fig. 3

723

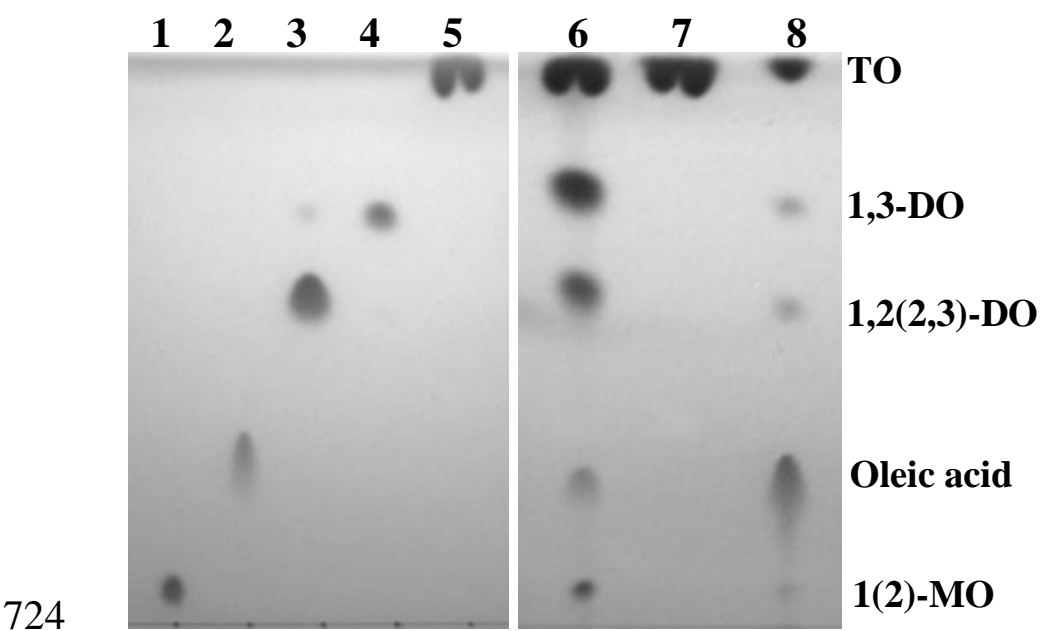

725

726

727

728

729

730

731

732

733

734

735

736

737

738 
Fig. 4

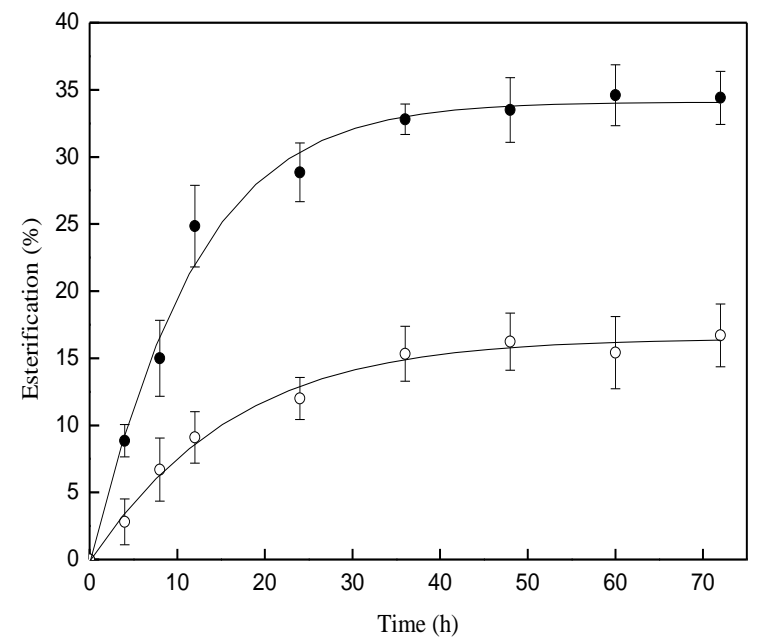

740

741

742 